\title{
Internet use and its importance in Kosovo
}

\author{
Hysni Terziu
}

Prof.Ass.Dr. , Universiteti Publik “UKSHIN HOTI, Kosovë

\section{Abstract}

The Internet as a communication medium, with its possibilities and its rapid development, revolutionized the way of doing business, so much so that it pushed a large number of economists to declare that, in the coming years of doing business through information technology, will be one of the most preferred opportunities for businesses and consumers across the globe. The main purpose of this paper is to identify the opportunities that businesses have to influence the economic development in the Republic of Kosovo, through their ability to generate new jobs, increase exports, and contribute to improving the living standards of the citizens of the Republic of Kosovo. Kosovo, using the Internet, as a contemporary and competitive form of business development. In order to realize such an environment, of course we have to consider two main issues, one to recognize and identify the problems that business has and another issue, how much human and material capacity Kosovo has, to provide a favorable environment. doing business online. The study realizes the first issue, which means that, in a scanned way, we tell the decision-making institutions that here are the administrative barriers that concern the business, here are the obstacles that unfairly tire the business, etc. The second issue should be asked by the relevant institutions and it should be noted that, if we want a success and sustainable economic development, then Kosovo should also provide an attractive business environment by applying the Internet.We conclude that favorable conditions must be created for the development of business and the Internet, in order for it to be efficient and sustainable, which is a necessary precondition for achieving the main goals of a sustainable economy, which contributes to the generation of countries. new jobs, improving the welfare and living standards of citizens in the Republic of Kosovo.

Keywords: Internet, development, economy, business, services, information, Kosovo.

\section{Introduction}

With the development of information technologies in general, and with the design of the first computer network in the world, through a new language of communication, both geographical barriers and time barriers in everyday digital communication were 
overcome. This unlimited communication between computers directly resulted in unlimited communication between people.

The rapid development of the Internet has raised many issues that need to be addressed very seriously by companies, among them are: Internet network dependence, security and privacy, identity

individual and organizational on the Internet, individual and organizational similarity, differences and relationships with their identities in the physical-real world (Li, 2007) and others. The intensity of the impact of the above mentioned issues varies from company to company depending on their type of business and their business model. Companies grouped into three types of traders, analyzed in the article Understanding e-business, can best be presented visually as in Figure 1 where all types of companies are distributed in a bar at the ends of which are traditional pure traders, in one, and pure online traders, in the other. Thus, moving from left to right more companies activities and / or processes are concentrated on the Internet, and less in the traditional aspect. Moreover, the more a company is involved in an Internet environment, through structures and investments in technology and other elements which constitute technological-information development, the more the connection of this company with the Internet increases and, logically, also increases her internet addiction. In this view, for example, Internet-based companies use the Internet for every aspect and every process of their business including accepting purchase requests, inventory control, production planning, implementing communication plans, software development and sales activities, development of plans and activities of services and other ancillary programs. Thus, these companies support their core activities entirely online creating challenges and risks that require new ways of thinking to plan responses to potential incidents and the development of new environmentally friendly business models. (Business Roundtable, 2007) ${ }^{1}$.

\section{The importance and use of the Internet in Kosovo}

Nowadays the Internet is the key technology that enables businesses, especially small and medium enterprises (these enterprises in English are known by the acronym SMEs from the words "Small and Medium-size Enterprises", to adopt it internationally to improve their performance ${ }^{2}$. In this respect and in all other respects, the internet is a living system which day by day is becoming bigger, better, as well as more secure with each contribution of private persons and / or various organizations. From this last argument emerges the need of companies to consider more than just the adoption of a modern technology, but also the aspects which have

\footnotetext{
${ }^{1}$ Business Roundtable. (2007). Growing Business Dependence on the Internet - New Risks Require CEO Action. Business. Washington DC.

2 Johnston, D. A., Wade, M., \& McClean, R. (2007). Does e-Business Matter to SMEs? A Comparison of the Financial Impacts of Internet Business Solutions on European and North American SMEs. Journal of Small Business Management, 45(3), 354-361.
} 
a direct impact on the vital processes of their business.

The Kosovo Information and Communication Technology Association (STIKK), supported by the Ministry of Foreign Affairs (MFA), the Norwegian Embassy in Pristina and the British Council, released a new report on Internet penetration and use in Kosovo.

The report states that internet penetration throughout the territory of Kosovo is in line with global norms. Internet penetration based on users is $76.6 \%$, while $84.8 \%$ for households.

This report provides an update to the 2012 STIKK report providing a brief summary of internet use in Kosovo in 2013.

The main findings include: "Kosovo's internet penetration based on users is $76.6 \%$, a percentage that is almost the same as in developed countries; in a 2013 report published by the International Telecommunication Union it was estimated that internet penetration in developed countries is $77 \%$. If the figure is released for households, internet penetration in Kosovo is even higher, $84.4 \%$. An assessment of the geographical penetration of the internet shows that there are, on average, 9 wireless networks per kilometer throughout the regional roads in Kosovo". "The citizens of Kosovo use the Internet at least to the same degree as the citizens of Europe, if not more. The study found that $86.8 \%$ of internet users in Kosovo use it the least on a daily basis. Almost $80 \%$ of internet users in Kosovo use the internet for communication, while Facebook is the most popular social media platform in Kosovo, while English is the main language used by new users.

According to the report, over a third of internet users in Kosovo would prefer to conduct online transactions if such a thing were possible. The report was implemented by STIKK 1 , with the support of the Ministry of Foreign Affairs of the Republic of Kosovo.

Kosovo is currently ranked 32nd in Europe (95th in the world) for the level of Internet service users. Whereas, in the Balkan region it is ranked in 4th place, after Greece, Croatia (EU members), and Turkey (candidate countries for EU membership), and before Albania and Macedonia. Kosovo is currently estimated to have more than 120,000 Internet subscribers and these figures are growing day by day. The biggest Internet users are considered to be young people.

This rapid increase in Internet use by Kosovars comes as a result of the drastic fall in Internet prices, the need to communicate with relatives, and also as a result of the recently increased competition from telecommunication service providers.

Kosovo currently has the most Internet service providers in the region, otherwise

1 The report was implemented by STIKK, with the support of the Ministry of Foreign Affairs Republic of Kosovo. 
known as ISPs (Internet Service Providers). In a small country with a geographical area of only 10,887 km2, Kosovo has 4 main ISPs, and about 20-30 local ISPs that mainly provide Internet services in regions and rural areas of the country. In the countries of the region we have a slightly weaker situation, they are currently ranked 42nd in Europe (instead of 107th in the world) for the level of Internet users.

While in the Balkan region is ranked penultimate for the percentage of Internet users, while only Serbia is below. However, Albania is the last in terms of the number of active Internet subscribers.

It is worth mentioning that in Kosovo access to the Internet is provided by some companies that provide services such as ISP (Internet Service Provider) and they are: "IPKO", "PTK", "Koha Net", "Kujtesa".

\section{Kosovo businesses and the use of online banking services}

Internet use by Kosovar businesses remains a limited tool. This is related not only to the location of businesses, or the access they have to this service, but also to the facilities that are offered. Internet banking is one of the services used by only $37 \%$ of all companies interviewed in the survey conducted in July this year, use Internet banking.

Of the 49 businesses that said they did not have internet access, 35 percent cited them as saying "they do not need internet", 18 percent said "there are no internet providers in their business location", 14 percent identified "Cost" as a reason and 31 percent mentioned other reasons.

Through the E-commerce service, ProCredit Bank Kosova becomes the first institution in Kosovo that offers businesses and traders in Kosovo the opportunity to sell their products and services on the Internet. Through this service, businesses will be able to accept payments from all VISA cards.

"E-Commerce service will open a completely new sales opportunity and will enable Kosovo businesses to place their products and services to a larger audience in the country and the region. This is a very efficient way to increase sales in a very efficient way, by promoting products or services on websites and accept online payment instantly ", announces ProCredit Bank, the first who implemented the Procredit payment platform Online banks are IPKO and SMARDONLINE. COM.

\section{How much internet services are used in Kosovar businesses}

The use of the Internet and other electronic services by Kosovar businesses can be considered as a stage of education of the population. The use of time equipment that more than anything cuts costs and time in the activity of a business, remains a form still very limited for many subjective reasons. This has to do not only with the location of businesses, or the access they have to various electronic services and the Internet, but also with the facilities offered and the cost of installing these services. 
According to a report made by the Institute for Economic Studies ${ }^{1}$. it turns out that the situation of businesses in Albania is still primitive and a lot of work is done by the individuals or owners who run these businesses. Thus according to the report, online bank payments is one of the services used by only 27 percent of all companies interviewed in the survey conducted in July this year. "Comparing the data of businesses surveyed in 2007 with those of large taxpayers in 2008 shows a slight change, only $4 \%$ increase, in the percentage of use of banking services through the Internet," the report states. This survey shows that internet banking services are used to the same extent by businesses located in Tirana, as well as those outside the capital.

The authors of the report point out that medium and large companies are the ones that lead more than small companies to use internet banking services. "Only 13 percent of the category of small companies with 1-5 employees use banking services through the Internet," the report states. These results are directly related to the fact that companies know the Internet, the opportunities it offers to perform services, etc.

Of the 49 businesses that said they did not have internet access, 35\% cited as the reason that "they do not need internet", $18 \%$ said that "there are no internet providers in their business location", 14\% identified the cost As reasons and 31\% mentioned other reasons.

Business-to-business-to-consumer (B2B2C). A special case of B2B is B2B2C (business-to-business-to-consumer). With B2B2C enterprises sell to enterprises but also distribute even smaller values to individuals or small enterprises (consumers).

\section{E-commerce in Kosovo}

It is common to think that the Internet will increase the emerging gap between rich and poor countries. In reality, a large part of e-commerce depends more on intensive learning than on capital. We can freely say that no country or company in the world can say that it has a long experience in e-commerce. In other words everyone is almost novice in the field. Since one of the biggest expenses of an internet utilization strategy is human resources. Kosovars who are business leaders should take advantage of this free labor force and the young age of the population, here they have an advantage.

On the smardonline. Com for the first time you can order goods from the internet with moto, Be wise supply from smardonline.com.

Smardonline enables not only the purchase but also the delivery of goods at home. Shipments were made throughout Kosovo within 24 hours. The minimum condition for deliveries in Prishtina is 10.00 euros while outside Prishtina 50.00 euros. Here you can order at any time, for deliveries in Prishtina you pay for transport 1.00 while outside Prishtina $2.50 €$.

${ }^{1}$ According to the Report from the Institute for Economic Studies 
Payments can be made as follows:

- Cash

- Visa / Master from Raiffeisen Bank or Procredit Bank

- Banker transfer

- Pos terminal

To be able to place an order from this E-Shop, buyers must first be registered in the registration form where personal data must be entered, receiving a password that only the buyer must know due to non-misuse. Selected products can be placed in the basket but also the opposite are removed from the basket and choose other products. The purchase ends with sending the order.

Smardonline has a mobile version of opening on smartphones and tablets, which gives easier access to product selection for the customer. The latest version of Internet banking has been introduced, which enables the sale and purchase of products and services online in Kosovo. Through the E-commerce service, ProCredit Bank Kosova becomes the first institution in Kosovo that offers businesses and traders in Kosovo the opportunity to sell their products and services on the Internet. Through this service, businesses will be able to accept payments from all VISA cards. "E-Commerce service will open a completely new sales opportunity and will enable Kosovo businesses to place their products and services to a larger audience in the country and the region. This is a very efficient way to increase sales in a very efficient way, by promoting products or services on websites and accept online payment instantly ", announces ProCredit Bank.

Any business that wants to expand its sales on the Internet through the services of ProCredit Bank has the opportunity to participate by expressing interest in business advisors dedicated to their business.

With the support of the 3-D Secure security platform ${ }^{1}$ (Verified by VISA), ProCredit Bank creates a safe environment to launch the first steps of this activity in the Kosovo market.

From the perspective of cardholders in Kosovo, the launch of the E-commerce service means the addition of a new and very convenient way to purchase local products and services from their office or home 24 hours a day, seven days a week.

The security technologies used make it impossible for third-party card records to be stored.

ProCredit Bank will continuously make efforts in cooperation with local businesses to create as much value for the cards of citizens in Kosovo, enabling the payment of

1 3D secured - level of security when shopping online, provided by VISA 
as many products and services from the Internet.

\section{Recommendations}

$>$ In the future all businesses that will seriously orient their business in general and the marketing factor in particular towards electronic (e-marketing) will first need to provide an efficient website which is easy to access. used by online users and an easy and secure system for in-house staff.

$>$ Kosovar companies must become part of this wider community, to be included in the new era of virtualization and modern technology.

$>$ The Internet enables us to quickly advertise worldwide to anyone who is interested in our products or services.

$>$ Refle to reflect our activity through electronic marketing, means to be identified faster and more, means to be more successful than others, summarizing it all in a single sentence; means we have found the gateway which enables us a wide publicity.

$>$ Considering the research conducted, it is recommended that businesses improve internet marketing.

$>$ E E-marketing oriented businesses should offer discounts on their products and services using the same purchasing motivation method as traditional marketing.

$>$ Electron Electronic payment to offer greater freedom to individuals in paying taxes, licenses, fees, etc.

$>$ Reduce deployment costs and make information dissemination easily accessible.

$>$ Electron E-marketing to be used with the primary purpose of reducing costs and saving time.

\section{Completion}

With the development of information technology and the rapid spread of social networks, businesses are selling more through the internet, albeit not in an organized form. Both market players and postal operators report an increase in the volume of deliveries. Informality and high use of cash in the economy continue to be a problem. How much do Kosovars spend to shop online and how does Kosovo rank in relation to the region and EU countries for online sales?

The internet sales market in Kosovo is continuing to grow rapidly. The growing trend of sales is confirmed by both market players and postal operators who deal with the delivery of packages by the business. However, informality and high use of cash remain the main problems. Leading market players expect the performance to continue to be positive. First, they base their sales on customers in the 17-35 age group and view them as a target group who return to their online shopping experience. Second, with the development of technology and the increasing use of smartphones, consumers are increasingly inclined towards this consumer behavior. 
From Gjirafa.com, one of the online sales portals, they say that the online sales sector in Kosovo is growing. This is certainly good news for businesses operating in the market. "The bad news has to do with the increase of informality in this sector, the specificity of which creates the possibility that anyone can sell from home, without registering with KBRA, without offering any kind of guarantee for the products sold. This is also favored by some distribution companies, which operate in cash and not through banks. "As a result, businesses that are formal and taxpayers are put in difficulty, slowing down growth."

\section{Literature}

[1] Arsenovski Sime, Informatics, Skopje, 2006

[2] Arsenovski Sime, Informatics, Skopje, 2006

[3] Besim V Avdullai / Electronic Business / University of Tetova 2008

[4] Burke, Raymond R. (2002), Technology and the Customer Interface: What Consumers Want in the Physical and

[5] Dr.Berisha Mihane, Business Informatics-Lecture2004part: Computer Networks

[6] Dr.Mustafa Muhamet, Business Informatics, 2004

[7] Dr.sc.Beqiri Edmond, Internet-Computer Communications- Dukagjini, Peja, 2002

[8] Dr.sc.Driton Sylqa and Denis Gafuri / Services and Importance of Electronic Business

[9] http://quartsoft.com/blog/201302/increase-your-online-sales-in-2013webinar

[10] http://quartsoft.com/blog/201302/increase-your-online-sales-in-2013webinar

[11] http://www.zawya.com/story/eCommerce is expected to grow globally $\mathrm{u}$ $\mathrm{p}$ to USD14trn in 2015-

[12] ISP - Internet Service Provider International Journal of Business and Administration Research Review, Vol.2, Issue.4, Jan-March, 2014 GN_05122013_061250 /

[13] MED / Electronic Communications Sector Policy / Digital Agenda for Kosovo 2013 - 2020 Verity, J.W., Hof, R.D., Baig, E.C., \& Carey, J. (1994). Internet: How it will change the way you do business. Business Week, November 14th.

[14] MTI / https://mti.rks-gov.net/page.aspx?id=1,66

[15] OEK /https://www.oek-kcc.org/

[16] Prof. Dr. Mihane Berisha Business Electronics (scripts)

[17] Searchcio / https://searchcio.techtarget.com/definition/e-business

[18] Statics in internet growth: www.internetworldstats.com/emarketing.htm

[19] Statistics on online shopping in: www.southafrica.info/news/ business / 141975.htm

[20] Turban, Efraim, Introductiontoe-commerc

[21] Turban, Ephraim, Introductiontoe-commerce 


\section{[22] www.smardonline.com}

[23] www.telegrafi.com

[24] Zhanjeta Ndregjoni / Application of electronic commerce to small and medium businesses / University of Tirana 2014 